\title{
Europe joins UK open-access bid
}

Britain plans to dip in to research funding to pay for results to be freely available.

\section{BY RICHARD VAN NOORDEN}

$\mathrm{B}$ eing the first to try something new is nerve-wracking - so it is always a relief to see someone else follow your lead. When the UK government announced on 16 July that it would require much of the country's taxpayer-funded research to be openaccess from April 2013, it was not immediately clear whether the move would set a trend or prove to be an isolated gamble - one that would leave the United Kingdom essentially giving away its research for free while still paying to read everyone else's.

But the next day, the European Commission (EC) matched the United Kingdom's vision, launching a similar proposal to open up all the work funded by its Horizon 2020 research programme, set to run in the European Union (EU) from 2014 to 2020 and disburse $€ 80$ billion (US $\$ 98.3$ billion). The details will be negotiated over the next year, but EC vice-president Neelie Kroes emphasized the momentum that open access has already acquired. "We are leading by example, making EU-funded research open to all - and we are urging member states to do likewise, so that sooner, rather than later, all nationally funded research will follow." The EC says that it is aiming for $60 \%$ of all European publicly funded research articles to be open access by 2016 .

The announcements weren't unexpected. Britain's policy follows last month's government-commissioned Finch report on open access (see Nature 486, 302-303; 2012), itself the culmination of more than a year of debate. The EC has made no secret of its support for open access, having run a pilot trial that covers some $20 \%$ of the budget of its current research-funding scheme, the Seventh Framework programme.

But coming in such quick succession, the statements mark Britain and Europe's determined plunge into an uncertain open-access transition that will dramatically shift the incentives for scientists, journal publishers and research institutions over the next five years.

Other funding bodies such as the US National Institutes of Health (NIH) and Australia's National Health and Medical Research Council already mandate a degree of open access. These agencies compel researchers to make their work publicly available in a separate repository within 12 months of publication - a version of 'green' open access that coexists with conventional subscription-based publishing.

But the UK Finch report advocated that authors should make their work free to read immediately on publication by paying publishers up front - the 'gold' open-access model. This is controversial among some researchers who argue that it sustains publishers' already high profits by eating into funds that could be used for research, and that the Finch report has played down the value of green repositories.

Although the UK policy recommends the gold route, it includes a much larger role for green open access than the Finch report envisaged. The plan is set out by Research Councils UK (RCUK), the umbrella body for the nation's seven research councils that award government grants. To cover the up-front charges for gold papers, the RCUK will pay $1-1.5 \%$ of its $£ 2.8$-billion annual research budget in block grants to research institutions. Each will use the money to set up a publications fund to pay for its researchers' papers, with the size of the award being proportional to each institution's research activity in recent years. Prepaid gold papers must have a liberal publishing licence, making text and data free to mine or reuse, the RCUK policy adds.

For journals that don't offer gold open access, the RCUK insists that they allow authors to deposit the final peer-reviewed version of a paper online within 6 months of publication (a system with which Nature complies). A longer embargo of 12 months is allowed for the arts, humanities and social sciences. The RCUK says that journals that don't allow either route should be shunned by researchers. The EC proposal matches this mixed green-gold model, right down to the 6-and 12-month publishing embargoes, but allows individual researchers to pay any author fees from their own grants.

To enforce its policy, the RCUK will probably tie compliance to future funding - much like the rule that the Wellcome Trust, a private UK research charity, announced in late June to beef up the $55 \%$ compliance of its own greengold open-access mandate. The RCUK hopes

"The fear that
the UK ends
up isolated is
not going to
happen."
after "a number of years" to approach the $75 \%$ compliance that the NIH has achieved for its green open-access policy, according to Astrid Wissenburg, chairwoman of the RCUK Impact Group, which is charged with increasing the economic and societal benefits of researchcouncil funding.

If researchers do fall in line, the wide adoption of open access will shift everyone's publishing behaviours. Scientists may start discussing with universities where, and how much, they can afford to publish. Publishers and learned societies that rely on profits from library subscriptions will have to be more transparent about the costs of publishing. The latest open-access journals, such as PeerJ and eLife, may gain from the resulting melee (see Nature 486, 166; 2012).

A large-scale change will depend on other countries following the United Kingdom and the EC; as Nature went to press, rumours were circulating that the US National Science Foundation was set to announce a new open-access policy of its own.

UK science minister David Willetts told Nature: "The fear that the UK ends up isolated is not going to happen - our policy will shape the international debate."

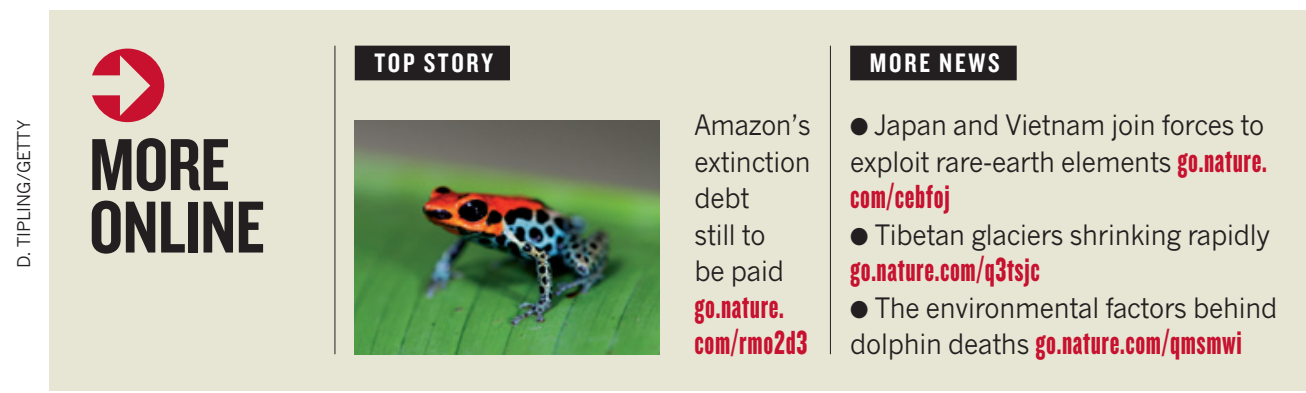

\begin{tabular}{|l|l|}
\hline VIDEO & $\begin{array}{l}\text { Raindrops } \\
\text { falling on its } \\
\text { head doesn't } \\
\text { bother a } \\
\text { hummingbird } \\
\text { go.nature.com/ } \\
\text { gnqmido }\end{array}$ \\
\end{tabular}

